Abstracta Iranica Abstracta Iranica

Revue bibliographique pour le domaine irano-aryen

Volume 26 | 2005

Comptes rendus des publications de 2003

\title{
Honar-e Hātam / The Art of Khatam. Tehrān, SAMT, 1382/2003, 319 p., pl., biblio., expressions, vocabulaire.
}

\section{Morteza Kotobi}

\section{(2) OpenEdition}

\section{Journals}

Édition électronique

URL : http://journals.openedition.org/abstractairanica/2369

ISSN : 1961-960X

Éditeur :

CNRS (UMR 7528 Mondes iraniens et indiens), Éditions de l'IFRI

Édition imprimée

Date de publication : 15 mai 2005

ISSN : 0240-8910

Référence électronique

Morteza Kotobi, « Honar-e hātam / The Art of Khatam. Tehrān, SAMT, 1382/2003, 319 p., pl., biblio.,

expressions, vocabulaire. ", Abstracta Iranica [En ligne], Volume 26 | 2005, document 332, mis en ligne le 07 décembre 2005, consulté le 25 septembre 2020. URL : http://journals.openedition.org/

abstractairanica/2369

Ce document a été généré automatiquement le 25 septembre 2020.

Tous droits réservés 


\section{Honar-e Hātam / The Art of Khatam. Tehrān, SAMT, 1382/2003, 319 p., pl., biblio., expressions, vocabulaire.}

\section{Morteza Kotobi}

1 L'A. de cet ouvrage s'attache à montrer l'actualité d'une technique artisanale traditionnelle. En huit chapitres, il étudie successivement l'origine du Huătam et son apparition dans différentes civilisations (Chine, Inde, Égypte, Syrie, Turquie, Italie et Espagne), l'historique de son développement en Iran depuis l'époque safavide, les matériaux (bois de différentes essences) et les outils utilisés; la technique de fabrication fait l'objet d'un chapitre abondamment illustré de planches en couleur, tandis que la fin de l'ouvrage est consacrée aux maitres créateurs et aux centres de production.

2 Une bibliographie, un lexique et un index complètent heureusement l'ouvrage.

\section{INDEX}

Thèmes : 10. Histoire des Sciences et des Techniques

\section{AUTEURS}

MORTEZA KOTOBI

Université de Téhéran 